療により腫县が消失した後も、化学療法を続けること を必ずしも希望しないことによる。

根治的な局所治療後に効果的な $\mathrm{AC}$ を行うために 法，化学療法の投与によりその予後の改善が期待でき る症例の選択が必要である. Stage I で根治的な治療 が行われた場合では ACの有無に上り生存率には差が 出ない。恋た Stage IVで切除不能な局所進展癌では局 所治療後の予後は極めて悪い. 対象となる症例は Stage II〜IVで局所制御が可能な症例である.この症 例を予後因子で層別する，現在予後に関与すると考え られている因子は，原発部位・進展度・治療法である。 2 群它 $\mathrm{AC}$ の楽凨投与群と非投与群にわけ， $\mathrm{AC}$ 治療 後に予後 (非再発生存率) を比較する。AC が充分に有 効な方法であれば，2 群の間に有意の差がでることに なる.

頭頸部扁平上皮癌の進展症例を対象とした NAC 家 たは $\mathrm{AC} の$ 臨床比較試験の結果が報告されている。

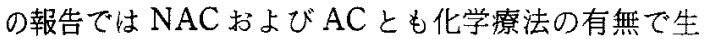
存率に差を認めていない，従って頭頸部扁平上皮癌で は局所治療の前 (NAC) または後 (AC) にルチーンに 化学療法を行うことは, 現在の方法では進展癌症例の 预を改善していない.今後薬㘊の選択・症例の選択 についての再検討が必要である.

$\mathrm{AC}$ の問題点について検討した. 1 つをその症例の
癌に有効な抗癌剤の選択である，個々の症例の癌細胞 に対する抗癌剤の感受性試験は臨床効果と必ずしも一 致しないこと, 進展癌においては癌の Hetrogenety が 明らかであり, 癌細胞の抗癌剤に対する多剂而性が問 題である．この問題を克服した新しい治療方法の開発

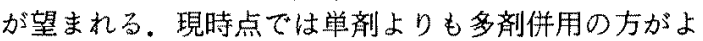
り良い効果が期待される。 また NACで臨床効果の認 められた症例に AC を行うことが選択法の一つである j.

もう一つは癌症例の予後因子の検討である．頭頸部 癌の癌治療を受けた症例においてその予後に大きく影 響する臨床的な因子として原発部位・進展度・一次治 療による局所制御の有無が考えられている. Stage II 〜IVの切除可能症例で一次治療で局所制御が出来たと 思われる症例でも約 $30 \%$ の症例で 2 年以内に再発が認 められている，根治治療後の局所再発または藏器転移 に関与する因子として，臨床的な因子だけでなく，最 近では癌細胞の病理学的・生物学的な悪性度が取り上 げられている。すすなち DNA content, Oncogene お よび各種 Tumor markers などである. 同じ進展度の 症例でもこれらの因子の有無によって予後が著明に異 なることが報告され，この悪性度は腫惶学的に重要な 検討議題となってきている. 化学療法を含好た癌治療 の選択に癌の悪性度を考慮したい。

\title{
9. 耳鼻咽喉科におけるリハビリテーション
}

\section{司会柴 田貞 雄（国立身障者リハセンター学院）}

近年, わが耳雤咽喉科領域ではりハビリテーション の重要性が改めて認識され, 本格的な取り組みが展開 されつつある。しかし，真にリハビリテーションが根 付き, 発展するには耳鼻咽喉科医がより密接にこれに 関わることが不可久で, そのような状況を作り出すこ とが必要である。それにはどうす心゙きであろうか？

リハビリテーションといえば，成果をあげるのに多 大の時日を要するばかりか, 効果あるいは変化に対し て明確に評価し難い印象がある。事実, 現状では大部 分, そうである。そのためか, 聴能, 平衡, 音声言語, 嬹下などのりハビリテーションは, comedical staff で ある各種の訓練士が行うものとの通念が固まりつつあ る.しかし，もしこの考えに流れてしまえば，医師は 患者を単に管理し，リハビリテーションの指示をする だけの人になり，その結果，いつまでもリハビリテー ションを実感できず, やがて興味も関心も薄らいでし まう恐れがある。これでは耳鼻咽喉科領域のリハビリ テーションを振興・発展させることは望むべくもない.

そこで、リハビリテーションに対処する耳舅咽喉科 の在り方として，次の2 つの努力日標を改めて設定し たい。すなるち,

(1)リハビリテーションの必要性をなくするか, 大幅 に滅じさせる。

(2)リハビリテーションの効率化を図る，である。
（1）ついては，例えば口蓋裂や䁷咽腔閉鎖機能不全 に対する手術法の開発や改良が構音障害の大幅な減少 をもたらすと共に，リハビリテーションの期間も短縮 させた。人工内耳もこのような著明な例と考え得る。 德下障害についてもしかりであるう。

(2)では，リハビリテーションに依存することから免 れられないにせよ，合理的な訓練法や評価法の開発の 余地が大である，例えば平衡障害に対する訓練法がそ うである。また，構音訓練や失語症の言語訓練では機 器・装置の開発が目賞ましくその有効利用が待たれて いる，等々である。

以上に述へたことは，耳鼻咽喉科医だけでリハビリ テーションを片付ける，片ー゙かないまでも comedical staff 八の依存度最小限にしようとするもので,つまる ところ，之のために積極的に当科固有の専門的知識や 技術を駆使する，という当然の結論になる。が，あら ゆる点で potential の高い㳊師がリハビリテーション に直接, 参加すれば臨床の成果は飛躍的に上がり, 技 術開発も促され，患者の受ける利益は測り知れない程, 大きくなるはずである。

パネルは, 從って「耳鼻咽喉科医が直接行うリハビ リテーションとその普及・開発」を考えるきっかけに することが狙いである。そこで普及や開発の程度に差 はあるものの, 医師が主体となってリハビリテーショ 
ンを行うとしたらどうあるべきか, 聴覚障害, めまい・ 平衡障害, 言語障害, 蟮下障害の 4 つについて, それ ぞれの角度から問題点を切り，リハビリテーション技
術の発展を展望する。パネリストの発表を中心に討論 を進める予定である。

（1）聴覚障害に対する人工内耳

伊 藤 真 郎 (東医大)

「リハビリテーション」を本来の広い意味での社会復 帰療法と考えれば，障害者に対する機能回復手術は医 師自身が行う積極的なリハビリテーションということ ができる. 聴賞障害者に対する人工内耳の実現は, こ の意味ではまさに画期的・奇跡的な社会復帰療法であ る. 今回は，上記のリハビリテーションという立場か らみた人工内耳について簡単に述べる。

メルボルン方式の $22 \mathrm{ch}$. 人工内耳の埋め込み手術症 例は, 本邦では教室の船坂が昭和60年に第 1 例を行っ て以来, その後他施設で行われたものを含めると, 症 例数はすでに50例以上になる。これらの人工内耳装用 者の言語聴取能については各施設でそれぞれ報告さ れ, いずれも良好な成績が得られている。

ところで，人工内耳装用者で結成された友の会では $\lceil\mathrm{ACITA}$ 」と称する会紙を発行しており，そのなかに は人工内耳の体験談や率直な印象が載せられている. それらは，医師側からの評価とはまた別の人工内耳の 実情を物語るものであり，人工内耳の効果と限界が理 解しゃすい.表 1 は当施設における症例の評価であり, 人工内耳の効果と限界が理解しやすい. 表 1 は当施設 における症例の評価であり，表 2 は装用者たちの印象 をそのまま抜粋したものである.個人差が大きいこと,

\section{表 1}

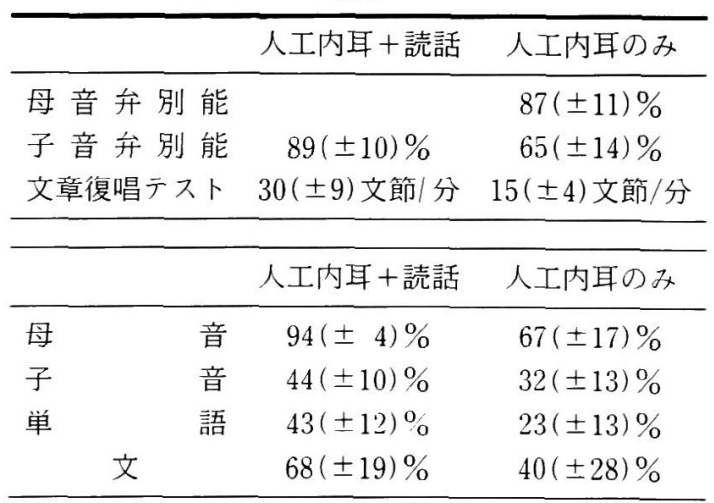

\section{表 2}

最初は音が耳障りで何の音か分からず，騒音のよ うで，すぐにスイッチを切りたくなった。

• 最初は「声は言葉として聴こえず，音が長いとか 短いとか,ザーザーとしか聞こえない」と言われ ていたが，最初から言葉が分かった。

長い間音の世界から遠ざかっていて，久しぶりに 自分の声を聴くことができた。

け自分の声が分かるので，大きな声で喋らなくなっ た.

けゆっくり喋ってもらって，なんとか話ができる。

、家族との会話はほとんどできるが，家族同士で話 していることはいまだに分からない.

、電話は特定の人の場合はなんとか分かる.

•今はほとんど筆談はいらない.

(20名の患者の印象・評価の抜粋)

表 3 Cochlear implant の適応

1. 会話領域で $95 \mathrm{~dB}$ 以上の両側高度感音難聴.

2. 補聴器を装用しても言語を判別できないもの。

3. promontory の電気刺激により, 聴神経の活動性 がある程度存在するもの.

4. X 線検査により, 螖牛の形態に異常のないもの.

視覚情報が必要なことなどが分かるが，総じて人工内 耳は実用に十分供するものであり，現在のところ塑に 対する最適な治療手段であることを強調したい.

表 3 に人工内耳の適応を挙げた。年齢については, 当初18歳以上としたメルボルン大学が, 現在では適応 を小児に拡大している。今後は peri-lingual, pre一 lingual への適応拡大・普及が期待される. 